\title{
Introduction to the Handbook on the EU and International Trade
}

\section{Sangeeta Khorana and María García}

\section{THE MULTIDISCIPLINARY NATURE OF TRADE POLICY}

International trade is, by its very nature, multidisciplinary. Trade exchanges are governed by both private commercial law contracts and public international law and determining what can be traded and how exchanges are to take place. The modern global trading system is underpinned by non-discrimination and governed by a set of global rules that spring from the post-World War II Bretton Woods agreements, in particular the General Agreement on Trade and Tariffs (GATT), which, as a centrepiece of 'embedded liberalism' (Ruggie, 1982), set the Western world, and later the rest of the world, on a path of gradual economic and trade liberalisation. Successive rounds of negotiations for greater trade openness led the way to the establishment of the World Trade Organization (WTO) in 1995, with a robust legal system for the resolution of trade dispute amongst states. With the faltering of the Doha Round and alongside the WTO's legal system, states have embarked on the negotiation of ever more comprehensive 'deep' trade agreements, amongst themselves. These international treaties create further rules (and institutional reforms) and legal systems for the management and governance of trade and investment relations amongst member states.

The gains from free trade have been unanimously acclaimed, and even the classical economists argued that open trade based on specialisation would engender greater efficiency and generate trade at lower costs (Smith, 1776; Ricardo, 1817). The downside of free trade is that whilst it generates gains, it can also lead to losses for certain groups that lose out to international competition. Due to its redistributive effects, which are much more than static trade creation and diversion in economic terms, trade is a highly political matter. Thus, tensions between advocates of trade openness and of protectionism have raged since the Industrial Revolution and continue to the modern times.

From a political perspective, supporting the interests of domestic constituents through protectionism makes sense (Milner, 1999). However, international regimes, especially since the 1980s (the WTO, World Bank Structural Adjustment Programmes) and transitions to capitalism, have brought forth a higher degree of liberalisation in the global economy, and rapid increases in global trade, until the advent of the 2008 financial crisis. Alongside this, a further 'unbundling' of production processes has taken place (Baldwin, 2013). The advent of 'glocal' production that led to global supply and value chains has resulted in products crossing borders multiple times in the production process, blurring the lines of national boundaries. An example is the production of iPhones that takes place across three continents - phones are designed and research into new product development takes place in the United States (US). Component parts are sourced from the USA, Europe and various Asian states. Assembly of the component parts into phones takes place in China. 
The addition of value to the phones takes place before they are warehoused in the US and finally distributed globally. The globalisation of production necessitates the movement of data and information across borders. Global value chains depend on seamless and uninterrupted information flows across companies and countries. Cross-border data flows have increased economic efficiency and productivity, raising welfare standards and standards of living. The increased importance of data flows to companies and citizens has also increased the topical relevance of data flows in trade-related negotiations. On the one hand, while these developments have brought about development and jobs to millions across the developing world, they have also resulted in environmental degradation and job losses as production shifts across the globe, on the other. Balancing these forces is the challenging task governments across the world are faced with. Their choices and actions, and the groups they choose to support and ignore, form the basis of the complex politics of trade and the core of the Handbook. It also recognises that in a world of rapid technological change and digitisation, trade policy must evolve to empower new forms of digital commerce and reduce barriers that hold back growth opportunities.

\section{HANDBOOK AIMS AND SUMMARY}

The need to understand trade policy from a multidisciplinary perspective, focusing on the legal, economic and political rationales and consequences of trade policy is the underlying ethos of this Handbook. The aim is to provide a single volume where readers, from students to practitioners, can encounter the legal basis of EU trade policy, determining the competences of each actor and their relationships and processes, and also the political conflicts that arise from this, and how the day-to-day political enactment of these processes stretches and modifies the evolution of the legal order. The subsequent chapters highlight the interplay of diverse economic interests with the politics of decision-making, and explore the highly political content of EU trade policy when it is deployed in the name of EU foreign policy. The Handbook introduces readers to the main actors and processes of EU trade policy, as well as the core political, legal and economic challenges facing the EU's trade policy. It covers recent critical developments in EU trade policy, especially the changed institutional dynamics resulting from the Treaty of Lisbon's enhanced powers for the European Parliament, and the polarisation of trade politics around the negotiations for the mega-regional agreement, the Transatlantic Trade and Investment Partnership (TTIP).

Part I includes the first three chapters and charts the historical path to today's trade policy, whilst highlighting the legal basis and presenting the economic and political rationales for such an evolution. Part II takes account of the key players in this process, their positions and impact on policies, and of the underlying principles and ideas that underpin their actions. Part III and the final part of the Handbook uncovers the interplay of these factors in a series of current cases, such as trade conflicts with Rising Powers, the use of trade as geostrategic power, or the nexus between trade and development, in order to provide empirically rich accounts of the key issues and challenges facing the EU's trade policy. Taken together, the collection offers the reader a comprehensive account of what the EU's trade policy is, how it works, and what it does in practice.

In all likelihood, critics will claim that the Handbook on the EU and International Trade is 'just another academic contribution', but we strongly believe readers should appreciate 
that to understand the agreement we need to look beyond the economic rationale and comprehend issues across disciplinary boundaries to understand the functioning of the evolving world order and visualise interconnections between various disciplines. This book does that and explores issues that impact trade policy-making from the practitioner and academic perspectives, thus marking the beginning of our journey in analysing the paradigms of EU trade policy.

Part I introduces the EU's trade policy from the perspective of the three main disciplines dealing with trade policy. In Chapter 1, Nicholas and Laurie Perdikis present the economic logics of market integration and trade liberalisation, and chart the joint evolution of the EU's single market and its external expression in trade policy. In Chapter 2, Clair Gammage traces the development of a legal regime governing EU trade policy. She focuses special attention on the division of competences between the European Commission, as the EU's 'single voice' in trade, and the member states, and the evolution of the concept of 'mixity'. In Chapter 3, María García familiarises the reader with the main characteristics of EU trade policy from a political science perspective. After presenting the main actors in EU trade policy-making and describing the policy process, the chapter turns to political explanations of EU trade policy based on institutional dynamics, the influence of interest groups and the power of ideas. It also introduces the tensions that arise from the EU's trade policy dual nature as commercial policy and a critical component of the EU's foreign policy toolkit, which are then further developed in subsequent chapters.

Part II focuses on the actors that determine EU trade policy. Chapter 4 presents the European Commission in its role as the EU's trade negotiator and international voice. In it, Lars Nilsson uncovers internal procedures for policy-making, with particular reference to decisions to engage in free trade agreement (FTA) negotiations with third parties, and the use of evidence-based impact assessments in trade policy-making. Chapter 5 explores the role of the Council of the EU in leading and shaping EU trade policy. Using a principal-agent framework, Johan Adriaensen analyses the dynamics between the Council and Commission, and the complexity of a policy system with multiple principals (Council, member states and European Parliament) vying for control of the policy. In Chapter 6, Guri Rosén explains the rationale for the expansion of European Parliament competencies over trade policy in the Treaty of Lisbon as a way of enhancing the democratic legitimacy of trade policy and aligning it with other policies. She also analyses the Parliament's exercise of its new powers in the ratification of the EU's FTA with the Republic of Korea and during the negotiations of TTIP. Chapter 7 delves into the increasing role of civil society in trade policy. From the turn of the century, the European Commission has expanded the mechanisms through which civil society can participate in trade policy, via online consultations and meetings with civil society, although in recent times it has been mobilisation and activism that has had the greatest impact on trade policy. Matthew Eagleton-Pierce explores these mechanisms and their outcomes in terms of influence in the policy process. He argues that the structural power position of such civil society actors remains weak compared to the relevant EU institutions, governments and leading transnational firms who have a stake in the trade policy game. However, trade-facing civil society organisations wield moral and expert forms of authority in ways that can complicate and disrupt conventional trade agendas. Chapter 8 concentrates on the role of business in shaping trade policy. It traces the evolution of business 
strategies for influencing trade policy as business models have become more global and intertwined with complex global production and value chains. Jappe Eckhardt argues that traditional international political economy assumptions that import-competing sectors can successfully mobilise to demand government protection, no longer holds, given the degree of variety in businesses today, and their different levels of integration in global value networks. As a result, direct lobbying by business becomes more challenging, and business-government relations are increasingly based on expertise, learning and information exchange rather than firms putting pressure on governments to ensure the imposition of tariffs or to enforce market access

Part III comprises a selection of focused case studies illustrating the challenges and dynamics of the enactment of the EU's trade policy. Chapter 9 highlights the deep interconnection between the EU's trade policy and its broader foreign policy aims on the global stage that turns it into a 'conflicted trade power' (Meunier and Nicolaïdis, 2006). In this chapter, Michael Smith highlights how through the creation of new institutional arrangements (e.g. the European External Action Service) and practices, the EU has attempted to improve 'joined-up' thinking and action in its trade and foreign policy. He examines a multitude of settings in which the commercial and political objectives are intertwined in the EU's external action, such as relations with Strategic Partners, with the developing world, with its neighbourhood, and in interactions in multilateral settings like the WTO. The examples demonstrate how "processes of global change and the evolution of multilateral institutions combine with powerful forces of politicisation and securitisation to create major pressures on the coherence and consistency of EU policies', which are evident in the deployment of sanctions or rewards, and the clash between the normative and the material concerns of EU external action. Crucially, Michael Smith concludes that this results in continuing dilemmas for EU external action, which cannot be solved simply by institutional adjustments, as has been attempted until now.

Chapter 10 continues the theme of linkages to foreign policy by homing in on the intersection between trade policy and geopolitical ambitions. Nicholas Ross Smith asks to what extent did the EU's foreign trade policies contribute to the eruption of the Ukraine crisis, and what can the EU learn from the Ukraine crisis in terms of using its trade power? He argues that whilst the EU's foreign trade policy was clearly not a direct cause of the Ukraine crisis, the zero-sum nature of the EU's Deep and Comprehensive FTA (DCFTA) offer and its miscalculations of the likely responses of Ukraine and Russia to this policy, did help to generate an environment conducive to competition between the EU and Russia and instability. Lessons from the Ukraine case include the need for EU policy-makers to better understand the dynamics of being an international actor, as its trade policy for its Eastern frontier demonstrated a glaring absence of geo-political and geo-economic awareness. This highlights the dilemmas outlined by Michael Smith in Chapter 9, and the persistent problems of lack of consistency and coherence in the EU's external action.

Chapters 11 and 12 continue the exploration of the deployment of trade policy to exert power in the international arena, in this case in relations with the developing world.

In Chapter 11 Tony Heron and Peg Murray-Evans concentrate on the nexus between the EU's trade and political aims as exemplified in the contentious Economic Partnership Agreements (EPAs) with developing states in the Africa, Caribbean, Pacific (ACP) group. They examine the aims and strategies in the negotiation of the EPAs by the EU. The authors suggest that the way in which the economic dimension of the EPAs, reciprocity 
and differentiation in matters of trade and investment, interacted with the political dimension of institution building and regionalism, generated a series of tensions in the EU's EPA agenda. The EU's decision to base the EPAs on an interregional negotiating model exposed the limited nature of the material leverage stemming from the asymmetrical trade relationship between the EU and ACP countries. Critically, the EU's commitment to compliance with WTO rules in designing reciprocal EPAs, while also offering special and differential treatment to the poorest African Caribbean and Pacific (ACP) countries, appeared to undermine the EU's political agenda centred on the promotion of ACP regional integration by creating a set of divergent economic incentives that cut across the proposed regional configurations. The chapter demonstrates how the intertwining of objectives can undermine the successful translation of EU policy objectives.

In Chapter 12, Lore Van den Putte and Samantha Velluti examine the EU's promotion of social values, in particular labour standards in its trade policy. They compare the conditional approach in the EU's unilateral trade policy for developing states, termed the Generalised System of Preferences scheme (GSP), to the promotional stance in its new trade agreements with Latin American states, and contrasts the legal aims and political practicalities of their enforcement. The findings suggest that a significant limitation of the EU's promotion of social trade is due to inconsistent practices particularly in the context of the unilateral trade arrangements and between the nature of the obligations in the latter and that contained in bilateral trade agreements where the promotional nature of social clauses is arguably stronger. Hence, the effectiveness and impact of these social clauses is dependent on the mechanisms used and the way that they are employed.

Chapter 13 considers the EU's trade policy as an expression of a particular ideology of economic liberalisation. Ferdi De Ville and Gabriel Siles-Brügge adopt a constructivist approach to underline the importance of ideas in trade policy-making. Focusing on the EU's flagship trade policy documents over the last decade, they uncover the key themes arising from various incarnations of EU trade policy. They identify three main paradigms emanating from the European Commission: 'free trade', 'trade as foreign policy' and 'fair trade'. Their discussion of TTIP illustrates how this process of discursive adaptation has played out in practice, with the 'free trade' paradigm increasingly being supplemented by (and indeed sometimes even playing second fiddle to) 'trade as foreign policy' as justification for the need of TTIP, and finally 'fair trade' and 'embedded liberal' paradigms in the 2015 'Trade for All' strategy in response to fierce public criticism of TTIP.

In Chapter 14, Philippe De Lombaerde, Ludger Kühnhardt and Mario Filadoro continue reflecting on the importance of ideas, by focusing on how the EU's positive view of regional integration has been promoted through its trade policy. The EU has done this through the promotion of inter-regionalism and conditioning trade negotiations to advances in regional integration elsewhere in the world. The authors trace of the evolution of the EU's interregional preference, and evaluate its implementation in relations with the Andean Community, the Association of South East Asian States and the EPAs. They track the switch from a region-to-region approach to a region-to-state approach with the 'Global Europe' trade strategy. As this implies a differentiated approach to members of the same region, they highlight the importance of flexible instruments such as the design of rules-of- origin (particularly the adoption of bilateral and regional cumulation) and trade-related assistance to support regional integration (channelled bilaterally and regionally). They argue that through these key elements, the EU can follow a bilateral trade 
negotiation approach, to satisfy its material interests, without setting aside its preference for inter-regionalism in the long-run.

Chapter 15 analyses the idea of fair trade as espoused in EU trade policy. Deborah Martens and Jan Orbie take a historical approach to uncover how the concept has been used and evolved in EU trade policy since it was first mentioned in the 1990s. They develop a conceptual matrix to assess fair trade policies according to their reliance on market-measures (neoliberal) or government policy intervention in trade policy (interventionist), and their degree of ambition in terms of changing production and trade relations (revisionist or revolutionary). They argue that the EU's trade policy has predominantly favoured market-oriented approaches to fair trade, as exemplified in the European Commission's hands-off approach to labelling or conceiving of fair trade as merely compliant with WTO rules. They also highlight some instances of a more interventionist approach at the behest of the European Parliament and Fair Trade lobbies, and the shift in this direction in the 'Trade for All' strategy of 2015, especially with regards to responsible global value chains, which the authors consider could result in a significant change in future EU (fair) trade policy.

Chapter 16 considers how the emergence of complex global supply chains has reconfigured the interests and aims of the EU's trade policy. Adrian Smith notes that despite the EU's recent explicit engagement with the language of global value chains in the context of its 'Trade for All' strategy, macro-regional trade policy has been (at least in part) about a long history of extending the reach of global and macro-regional economic relations via European-led global value chains. He supports this by tracing the historical evolution of the EU's trade arrangements with its immediate neighbouring countries in Eastern Europe and North Africa, at the core of which has been a process of global value chain integration. Smith demonstrates how EU trade policy seeks to extend the global and macro-regional reach of global value chains to enable production relations with third countries. He warns, however, that without understanding the inherent articulation between the uneven distribution of power relations between lead and supplier firms, the extent to which the progressive potential of wedding global value chains, sustainable development and trade policy together is likely to be limited.

Global production and trade networks also lie at the heart of Chapter 17, which places the focus of analysis on how their emergence over the last decades has affected the degree of competitiveness of European businesses and affected trade patterns. Taking an understanding of competitiveness as a multi-faceted concept determined by domestic macroeconomic conditions and international trade policy environments as his point of departure, Min Shu proceeds to link successive enlargements of the European market with increased complexity in determining a successful competitiveness agenda for Europe. Each enlargement has expanded the single market, but has also brought into the market a wider array of economic sectors with differing legacies of success and government support, which have been translated into various degrees of trade openness in the different member states, complicating the elaboration of the single commercial policy. Whilst enlargements have altered the domestic composition of EU competitiveness, Shu highlights international changes, particularly the evolution of global production and trade networks, and the emergence of 'Factory Asia' and 'Factory China' as critical junctures in the loss of competitiveness of European manufactures, especially in textiles manufacturing. The challenge this has posed to the EU has led to a number of high- 
profile trade disputes with China (textiles, solar panels, energy-efficient lightbulbs), as the EU has attempted to regain competitiveness through an appeal to fair and equitable trade practices. However, more than anything, the disputes discussed revealed the growing internal diversity within the EU, with different states, sectors and companies taking positions for and against the disputes, echoing disparities in business inputs into trade policy elaborated by Jappe Eckhardt in Chapter 8. Shu concludes that increased internal diversity in the EU and external challenges has led to a heated and unresolved debate on the required properties of EU competitiveness in international trade.

Trade disputes, likewise, lie at the heart of Leilla Choukroune's study (Chapter 18) of how the WTO's dispute settlement mechanism (DSM) has been increasingly used by developing states to challenge the EU, and the EU's response to this. She argues that developing states' use of the WTO DSM came as surprise to the EU, which had not planned for the possibility of being challenged by developing nations on the basis of its own legal terms and with its legal weapons. Choukroune concludes that recent disputes and heated debate on unfair trade and the acceptance or not of China as a market economy reveal the need for the EU to adjust its policy and dispute settlement strategy to the targets it is setting for itself in its policy papers, and in particular with regards to 'deepening and rebalancing' the relationship with China and encouraging and supporting 'China's growing role in the multilateral trading system'.

The final three chapters reflect the mirroring of internal market developments in the EU's external trade policy, focusing on how the growth of a services- and knowledgebased economy within the single market has propelled EU trade policy to take an active stance in promoting the facilitation of trade in services and the greater protection of intellectual property rights. In Chapter 19, William Kerr explains the economic significance of liberalisation in new trade areas (competition policy, services, public procurement, intellectual property) for the EU's trade policy as these have become heavily contested matters within the World Trade Organization (WTO). He then proceeds to set forth the articulation of a trade policy seeking to enhance trade in services within the example of the EU's free trade agreement with Singapore from 2012 to circumvent difficulties and opposition at the WTO (Chapter 20).

Finally, Chapter 21 comes full circle to the dual-track evolution of the single market and trade policy. In this final chapter, Sangeeta Khorana and Gregory Voss track the recent evolution and development of the Digital Single Market within the EU, commenting on the security and governance issues, and expand on the implications that these are likely to have on future trade policy developments.

\section{THE FUTURE OF TRADE POLICY}

As we prepare this Handbook for publication in latter half of 2017 there are clear indications that the international trade panorama and the contending forces for and against globalisation stand at a crossroads. The global trade arena is increasingly in the limelight as evidenced from the recent vote for Brexit and the changing focus of US trade policy. History provides ample evidence that conflicts over trade policy and globalisation are not new. The late 1990s saw strong mobilisation against trade liberalisation, aimed at the WTO. However, in the long aftermath of the 2008 financial crisis, the 2010 s have 
witnessed increased contestation of the EU's trade policy, and an intense re-politicisation of trade. Whilst in the 1990s mainstream political parties remained committed to a liberalising agenda despite non-governmental organisations' opposition, the emergence and rising popularity of new parties in Europe since 2008 willing to challenge that agenda is changing trade policy dynamics, and looks set to have a long-lasting impact on future trade policy.

The decision in 2013 to start negotiations for a TTIP between the United States (US) and the EU served as a rallying cry for diverse groups, ranging from consumer and environmental groups rejecting food standards to anti-capitalist groups, to mobilise and campaign against the deal. The reach of opposition was such that by late 2016 politicians across the EU feared association with the project, and publicly condemned the process. Germany's Vice-Chancellor and Economy Minister at the time, Sigmar Gabriel, stated to the press in August 2016 that 'The talks with the US have de facto failed because we Europeans of course must not succumb to American demands. Nothing is moving forward' (EurActiv, 2016a). Likewise, former French President François Hollande declared that 'knowing what stage the international negotiations are at, at this stage, France would say no' to TTIP (EurActiv, 2016b). By 2016, trade policy was firmly in the public spotlight, and the days of trade policy as an obscure technocratic arena gone. In October 2016, the Wallonian regional Parliament made global headlines after voting against granting its consent for the Belgian government to ratify the EU's Comprehensive Economic and Trade Agreement with Canada (CETA), fearing that it would be a precursor to TTIP. After assurance that CETA would not undermine EU standards, the Parliament agreed to it, but the initial rejection bears witness to the strong politicisation of trade policy and the responses it evokes.

Dovetailing in time, the US 2016 election, which brought President Trump to office, was characterised by a discourse of rejection of past trade policies, articulated especially vocally by Donald Trump. Other candidates, too, displayed more protectionist stances, including Democrat candidate Hillary Clinton, who had previously been a supporter of USA trade agreement policies, including the controversial Transpacific Partnership (TPP). Upon his inauguration as President, Donald Trump stopped ratification of the TPP, opened up a Pandora's box in terms of re-negotiating the North Atlantic Free Trade Agreement (NAFTA), and has taken an overall protectionist stance to trade policy in support of USA manufacturing. As a consequence of developments on both sides of the Atlantic, TTIP negotiations have been suspended, and future directions of global trade and trade policies are uncertain.

2016 was a historic year in trade policy on account of yet another historic event the UK decision to withdraw from the EU, with similar hallmarks of rejection of the socio-economic and political status quo. On 23 June 2016, the UK referendum on the EU returned a narrow victory $(52 \%)$ for the Leave camp. The United Kingdom is now negotiating the terms of its exit with the EU after triggering Article 50 on 29 March 2017. This decision came at a time when the EU is facing numerous crises: continued lacklustre growth in the Eurozone, a controversial influx of refugees and migrants, and security threats leading to rising Euroscepticism. These internal challenges have been further complicated by an increasingly turbulent international situation (conflict with Russia, Middle East wars, Chinese assertiveness, Trump's uncertain foreign policy). In the midst of this turmoil, the negotiation of the UK's exit from the European Union and its future 
relationship with the EU, will undoubtedly occupy the time, resources and efforts of European leaders and policy-makers, at the expense potentially of focus on other areas.

Negotiations for the UK's withdrawal from the EU, expected to last two years, as per Article 50 of the Treaty of Lisbon, mark unchartered territory for both the UK and EU an area no other EU country has dared to venture into. Negotiations are ongoing, and it is expected that the divorce will be extremely challenging and tense. What started off as 'Brexit means Brexit' has now been reduced to a whisper of a 'transition' arrangement, with talks likely to be prolonged beyond that two-year timeline. The UK Government White Paper states, 'We will need a free trade agreement and a customs agreement' (UK Government, 2017). Settling Brexit by 2019 (or even autumn 2018, so it can be ratified) is a major challenge. Nevertheless, at the time this volume goes to print, there are still too many question marks surrounding the process and its outcome to provide a thorough assessment of how this will affect EU trade policy, the EU-UK relationship and the UK's relationship with the rest of the world.

Whilst it is still too soon to make definitive predictions and assessments, there are some aspects of EU trade policy, dealt with in subsequent chapters, that will certainly be affected by the Brexit process, which we summarise below.

\section{Effect on Europe's Market Power}

Chad Damro's (2012) conceptualisation of the EU as a market power has at its core the existence of EU's single market, which may not hold in times to come. EU-28 possesses one of the world's largest coherent markets, with over 500 million consumers. In light of the size of the market, businesses aim to access the European market, and, through its trade policy, the EU has been able to extend improved access to its market in exchange for better access for its firms to other markets, as well as policy changes abroad (e.g. acquiescence with international labour standards). The withdrawal of the UK, the world's fifth economy with a population of around 65 million, from the EU will shrink the size of the EU's market both in terms of population and GDP, potentially making the EU market less attractive to businesses, and, crucially, making it more challenging for the EU to leverage its market size and attraction in its trade policy and trade negotiations. This is an issue that the EU has to factor in when negotiating the terms of exit with the UK. Further, EU trade relations with third parties are rife with disputes (see the chapters by Eckehardt and Choukroune), and its trade negotiations are increasingly contested (García and Masselot, 2015; Orbie and Khorana, 2015). As the chapters in this collection by Tony Heron and Peg Murray-Evans, and Lore Van den Putte and Samantha Velluti reveal, even in relations where the EU possesses leverage given developing states' greater dependence on the EU than vice versa, exercising the EU's market power is no straightforward affair.

The International Monetary Fund (IMF) has highlighted that the EU's share of global GDP has dropped since the financial crisis of 2008 from nearly 25 per cent of global GDP to roughly 21 per cent. The sustained problems in the Eurozone, sluggish growth across the continent until early 2017, and of course, the uncertainty engendered by Brexit, has again led the IMF (2016) to revise its growth forecasts for 2016 and 2017 for both the UK and the Eurozone downwards (1.8 per cent and 1.1 per cent in 2017 down from 2.2 per cent in 2015 and 1.7 per cent and 1.5 per cent for 2017 down from 2 per cent in 2015 , respectively). At the same time, continuing trends of greater growth rates in emerging 
countries than in the West, the IMF predicted much higher growth rates for China and other emerging economies (around 6 per cent or above). In this scenario, the trend towards diminishing the EU's market power is likely to be accelerated by the UK's withdrawal from the EU. What this may mean in the longer term is difficult to predict. Given opposition elsewhere to EU trade policy conditionality and linkages of trade and non-trade issues (social rights, democracy), the trade policy of an EU with reduced market leverage could become a trade policy more focused on commercial matters, and less imbued with foreign policy objectives. The EU's current trade policy, 'Trade for All' firmly enmeshed values and norm promotion in EU trade policy, so moves in the direction of a trade policy that is just about trade are unlikely in the short term. However, a pragmatic shift in the future acquiescing to others' preferences is not beyond the realms of possibility. If fact, pragmatism and attempts at adaptation to others have been common in EU trade policy over the last decade (Zimmerman, 2007; García, 2013, 2015; Mckenzie and Meissner, 2016).

\section{Effect on Future Trade Deals}

Beyond a possibly weaker negotiation position for the EU in future trade deals, Brexit changes the policy considerations of third parties. In November 2015, the Australian Prime Minister, and the Presidents of the European Council and European Commission issued a Joint Statement announcing their intention to work towards starting negotiations for a comprehensive trade agreement. The EU is a critical trade partner for Australia - its top source of foreign direct investment and its second largest trading partner (DFAT, 2017). Crucially, the UK accounts for around 30 per cent of Australian goods' exports to the EU and 46 per cent of services' exports. Whilst there are no indications that these negotiations will not proceed, and both Australia and the EU are keen to proceed, the dynamics of negotiations, will, of necessity be altered with the UK exiting the EU. A related issue is the EU's imminent concern that negotiating the UK's withdrawal may also have an impact on delaying new negotiations, purely related to resource constraints.

An immediate response to UK withdrawal from the EU, and to US President Trump's trade agenda, has been a renewed effort to finalise ongoing trade negotiations with third parties by the European Commission, and to position the EU as a counterweight to the apparently protectionist stances of the US. On 19 February 2017, the EU and Japan expressed their commitment to continue negotiations and their hopes for a speedy conclusion (DG Trade, 2017a), and the agreement has since been signed. Upon the European Parliament's ratification of the EU-Canada Comprehensive Economic and Trade Agreement (CETA) in February 2017, EU Trade Commissioner Cecilia Malmström stated that 'By building bridges rather than walls, we can face the challenges that confront our societies together. In these uncertain times, with rising protectionism around the world, CETA underlines our strong commitment to sustainable trade' (DG Trade, 2017b). Commission President Jean-Claude Juncker echoed this, when expressing the commitment to future FTA negotiations with New Zealand, which 'would also send a strong political signal of economic openness and trade at a time ... [when] protectionist pressures are on the rise not only on our own continent but also round the world' ( $N Z$ Herald, 2017). For the time being, it appears the EU is intent not only on continuing its trade policy, but in trying to capitalise from a possible US retrenchment from trade agreements. To what extent the EU will succeed with its hands so full is a space to watch. 
A further question mark lingers over the future relationship negotiated between the EU and a post-Brexit UK. The UK government, under the leadership of Prime Minister Theresa May, has repeatedly proclaimed its desire for a bespoke trade deal (EurActiv, 2016c) with the EU that goes beyond the EU's currently most advanced and liberalising negotiated trade agreements (e.g. CETA). Thus far, the EU has rejected an approach where the UK could opt to stay in the single market for certain aspects and not others (e.g. jurisdiction of the European Court of Justice and freedom of movement of people), as has the UK for a customs union with the EU. The stakes for both sides are incredibly high, and it is impossible to know what a post-Brexit UK-EU trade deal will look like, and if it will emerge at all. On the one hand, there is a scenario where, given the high degree of economic interdependence, and the fact that as a member of the EU, the UK has translated the EU's legal body into its domestic legislation (and could continue using it), an extraordinary deal is reached. But this is far from realistic in the current climate. The EU could use this rationale to prevent extending the same level of market access to third parties in subsequent negotiations. On the other hand, the EU may feel this is not a sufficient guarantee to secure its own negotiating position at the WTO or in future negotiations (e.g. with China, or if TTIP is resurrected at a later date), and may be unable to offer the UK the comprehensive trade terms the UK government is intent on. Furthermore, numerous EU FTAs already contain Most Favoured Nation (MFN) clauses for some sectors. For instance, the EU-Korea FTA contains an MFN clause for internal taxation and emissions rules for cars, meaning that if the EU in negotiation with another state gives car manufacturers better terms on these matters, those terms will also apply to South Korea, even if they have not been written into the EU-Korea FTA. In this sense, the UK's withdrawal from the Union, and a post-Brexit deal, could have a clear impact on the evolution of future EU trade policy.

\section{Relations with the Developing World}

As the chapter by Tony Heron and Peg Murray-Evans in this Handbook portrays, relations between the EU and developing states in the ACP region are underpinned by the Cotonou Agreement and the negotiation of EPAs. These negotiations have been protracted and, indeed, controversial. The EPA with Caribbean states was implemented in 2008, but others remain to be accepted by ACP states and implemented. Trade relations between ACP states and the EU often still display the legacy of colonial ties, with the strongest economic ties with former metropolises. For a number of ACP states, whose exports to the EU are concentrated in the UK, Brexit presents a dilemma. EPAs require acceptance of reforms (economic, but also procedural and governance reforms), in exchange for access to the EU market. If their exports are destined for the UK, but the EPA no longer applied in the UK's territory as it would no longer be part of the EU, the desire to acquiesce to EPAs may be diminished. Assuaging some of the anxiety raised in ACP states, in particular island states like St Lucia, whose exports to the EU are mostly destined for the UK, the UK government has made a commitment to guarantee existing terms of access to the UK market post-Brexit for developing economies and to explore avenues for the enhancement of these trade relations (Fox and Patel, 2017). However, even commitment to 'grandfathering' existing arrangements could cause challenges if legal and bureaucratic measures to ensure the grandfathering is not put in place in sufficient time (Razzaque and 
Vickers, 2016). Reverberations of the UK's withdrawal from the EU will, therefore, not be limited to the European continent but will resound far and wide and for years to come.

\section{POLITICISATION AND THE LEGITIMACY OF EU TRADE POLICY}

Trade policy's politicisation predates the UK referendum on the EU. TTIP negotiations served as a trigger in the EU to extend the level of public debate and mobilisation around trade. Prior trade agreements had barely received any mention in the press, but TTIP brought EU trade policy firmly into the public arena. The chapter by Ferdi De Ville and Gabriel Siles-Brügge details the rationale and experience of this politicisation. From an EU trade policy perspective, TTIP has brought forth some innovative responses in the policy process. The European Commission has committed itself to new levels of transparency in trade negotiations in its 'Trade for All' strategy of 2015, including improved communication with the European Parliament and enabling MEPs to access texts that are undergoing negotiations. Guri Rosén, in her chapter in this volume, also discusses this politicisation, which led to MEPs changing their stance on TTIP, from support for the negotiations in 2013, to a more cautious approach in 2015 requiring guarantees on the right to regulate, data privacy and the protection of public services. In this climate, national parliaments in the EU have adopted an activist approach to their ratification powers, with the Wallonian Parliament's initial vote on CETA being a case in point. These new dynamics will provide the backdrop against which the EU and UK will negotiate Brexit, and any future trade deal between them.

Politicians, with electoral cycles in mind, may be more easily swayed by loud groups in their constituencies, and may shift trade policy in new directions. Already ratification processes are being delayed (as occurred with CETA). At a time when the EU is beset with uncertainties, lack of clarity over the duration of ratification processes or concerns over whether a deal that has taken years to be negotiated will be rejected by one of the parliaments of the EU, will not be welcomed by third parties, and risk tarnishing the perception of an EU 'single voice' in trade and diluting the EU's market power.

Increased involvement of the European Parliament in trade policy since the Treaty of Lisbon of 2008, greater transparency, enhanced European Commission communication of trade policy and public engagement through stakeholder participation mechanisms, and activist mobilisation, alongside media reporting and more debates in national parliaments, could be said to increase the input of legitimacy in EU trade policy. By bringing policy to the public arena from the closed technocratic environment often occupied by trade experts, it is possible to bring accountability to bear in this policy area and exert greater democratic control over the future of trade policy. On the other side of the coin there is greater complexity, the impossibility of balancing all positions and interests, increased time spent negotiating positions with multiple groups within the EU's policy process, and risks of debilitated credibility. In the extreme, this could lead to policy paralysis, and a destabilisation of the 'single voice' in trade that has enabled the enactment of EU 'power through trade' (Meunier and Nicolaidis, 2006). Fritz Scharpf's $(1988,239)$ 'joint-decision trap' seems an apt description of the new dynamics and renewed politicisation of trade policy: 
Democratic governance introduces a tension between effectiveness and democratic legitimacy. We enlarge the scales of government on the justification that collectively we can attain goals that would not be possible individually. We attain this increased effectiveness at some cost to our ability to control our fate, because as the scale of government increases the less easily all individual preferences can be integrated and translated into outcomes.

\section{REFERENCES}

Baldwin, R. (2013), 'Trade and industrialization after globalization's second unbundling: How building and joining a supply chain are different and why it matters', in Globalization in an age of crisis: Multilateral economic cooperation in the twenty-first century, Chicago, University of Chicago Press, pp. 165-212.

Damro, C. (2012), 'Market Power Europe', Journal of European Public Policy, 19(5), 682-699.

DFAT (2017), Australia-European Union Free Trade Agreement, Department of Foreign Affairs and Trade, Government of Australia, available at: http://dfat.gov.au/trade/agreements/aeufta/Pages/aeufta.aspx

DG Trade (2017a), 'Commissioner Malmström and Japan's Minister of Foreign Affairs confirm commitment for an early conclusion of EU-Japan FTA negotiations' Press release 19.02.2017, available at: http://trade. ec.europa.eu/doclib/press/index.cfm?id=1625

DG Trade (2017b), 'European Commission welcomes Parliament's support of trade deal with Canada' Press Release 15.02.2017, available at: http://europa.eu/rapid/press-release_IP-17-270_en.htm

EurActiv (2016a), 'Germany says TTIP dead in the water', available at: http://www.euractiv.com/section/ trade-society/news/germany-says-ttip-dead-in-the-water/

EurActiv (2016b), 'Francois Hollande buries hope of concluding TTIP this year', available at: https://www. euractiv.com/section/all/news/hollande-burries-any-hope-of-ttip-conclusion-this-year/

EurActiv (2016c), 'Britain wants bespoke Brexit that deals with immigration', 29.07.2016, available at: http:// www.itv.com/news/update/2016-10-21/may-presses-eu-for-a-bespoke-brexit-deal/

Fox, L. and P. Patel (2017) Government pledges to help improve access to UK markets for world's poorest countries post-Brexit, Department of Trade Press Release, available at: https://www.gov.uk/government/news/ government-pledges-to-help-improve-access-to-uk-markets-for-worlds-poorest-countries-post-brexit

García, M. (2013), 'From idealism to realism: EU preferential trade agreement policy', Journal of Contemporary European Research, 9(4), 521-541.

García, M. (2015), 'The European Union and Latin America: "Transformative power Europe" versus the realities of economic interests', Cambridge Review of International Affairs, 28(4), 621-640.

García, M. and A. Masselot (2015), 'EU-Asia Free Trade Agreements as tools for social norm/legislation transfer', Asia Europe Journal, 13(3), 241-252.

Mckenzie, L. and K.L. Meissner (2016), 'Human Rights Conditionality in European Union Trade Negotiations: the Case of the EU-Singapore FTA', Journal of Common Market Studies, DOI: 10.1111/jcms. 12522.

Meunier, S. and K. Nicolaïdis (2006), 'The European Union as a Conflicted Trade Power', Journal of European Public Policy 13(6), 906-925.

Milner, H. (1999), 'The Political Economy of International Trade.' Annual Review of Political Science, 2(1), $91-114$.

NZ Herald (2017), 'Bill English talks trade with EU leaders Donald Tusk and Jean-Claude Juncker', 11.01.2017, available at: http://www.nzherald.co.nz/business/news/article.cfm?c_id=3\&objectid=11780074

Orbie, J. and S. Khorana (2015). Normative versus market power Europe? The EU-India trade agreement. Asia Europe Journal, 13(3), 253-264.

Razzaque, M. and B. Vickers (2016), 'Post-Brexit UK-ACP Trading Arrangements: Some Reflections', Commonwealth Secretariat Trade Hot Topics, Issue 137, available at: http://thecommonwealth.org/sites/default/ files/news-items/documents/5jln9q109bmr-en.pdf

Ricardo, D. (1817), On the Principles of Political Economy and Taxation, London, John Murray.

Ruggie, J.G. (1982), 'International regimes, transactions, and change: embedded liberalism in the postwar economic order', International organization, 36(2), 379-415.

Scharpf, F.W. (1988), 'The joint-decision trap: lessons from German federalism and European integration', Public administration, 66(3), 239-278.

Smith, A (1776), The Wealth of Nations, London, W. Stratham \& T. Cadell.

UK Government, DIT (2017), Preparing for our future UK trade policy - White Paper, available at: https:// www.gov.uk/government/publications/preparing-for-our-future-uk-trade-policy

Zimmermann, H. (2007), 'Realist Power Europe? The EU in the Negotiations about China's and Russia's WTO Accession', Journal of Common Market Studies, 45(4), 813-832. 
Sangeeta Khorana and María García - 9781785367472 Downloaded from PubFactory at 04/26/2023 12:38:43PM 